\title{
Sustainable Railway Infrastructure and Specific Environmental Issues in the Republic of Serbia
}

\author{
Milica VILOTIJEVIĆ, Mirjana VUKIĆEVIĆ, Luka LAZAREVIĆ, Zdenka POPOVIĆ
}

\begin{abstract}
Transport represents both need and threat to the modern human society. European transport policy aims at sustainable transport development based on the efficient use of natural resources, protection and improvement of environment, as well as the real and diverse needs of potential users. The paper points out that the development of railway infrastructure is a necessary but not sufficient condition for shaping the sustainable mobility. Railway infrastructure has to meet the requirements of the society, economy, protection and improvement of the environment. In general, electrification of railways leads to reduction of the carbon footprint. On the other hand, thermal power plants in Serbia are the main suppliers of electric power. The results of previous geotechnical laboratory testing showed that investigated fly ash could be suitable for utilisation in the railway infrastructure. This paper presents the results of laboratory tests to determine the presence of radionuclides and trace elements in fly ash samples.
\end{abstract}

Keywords: environment; fly ash; leaching; radionuclides; sustainable railway infrastructure; trace elements

\section{INTRODUCTION}

The modern world is obliged to conduct a sustainable economic policy based on the efficient use of natural resources, protection and, if possible, improvement of the environment [1-4]. This policy requires a prevention of environmental pollution and promotes sustainable industry, energy and agricultural production, transport, tourism and consumption [5]. In addition, the preferred economic development does not cause a further growth of environmental degradation. This is an extremely hard task.

Transportation represents very important economic sector both globally and in Serbia. An effective transport directly and indirectly contributes to growth and development of other economic sectors. At the same time, emission of greenhouse gases, noise, traffic jams, climate change and accidents threaten human health. Additionally, construction of the transport infrastructure irreversibly consumes natural resources and pollutes the environment. Therefore, transport represents both need and threat to the modern human society.

Ecological awareness of people is not a sufficient condition for the shift from other modes (especially road and air) to rail transport. Railway infrastructure, vehicles and related services have to comply with the specific requirements of the modern transport $[6,7]$. Regardless of the official transport policy, the 'modal shift to rail' concept is being implemented too slowly on the transport market in Serbia and worldwide. At the same time, 'modal shift to rail' should be followed by the reduction of greenhouse gases emission in road transport $[8,9]$, as well as the reduction of usage of non-renewable natural resources for road subgrades and embankments $[10,11]$.

Modern railway infrastructure has to meet the needs of users, the social development goals, as well as the requirements of sustainable transport development [12-17]. According to [15], a modern railway infrastructure and vehicles must provide equal conditions for all categories of passengers $[18,19]$. In addition, they must provide safe and simple use regardless of a potential visual, hearing, stature, mobility or intellectual impairment.

This paper considers the sustainable transport and environmental requirements for railway infrastructure in
Serbia. Furthermore, the specifics of 'modal shift to rail' transport concept and related environmental issues and experiences are presented [20-23]. Research presented in this paper is part of the broad research project that started three years ago and includes the following topics: Engineering - Civil, Engineering - Environmental, Transportation, Materials Science - Characterization and Testing, as well as Construction and Building Technology.

The aim of 'modal shift to rail' concept is to develop new and reconstructed infrastructure according to the actual needs of users of cargo and passenger transport. Special attention was drawn to the planned railway electrification, which would lead to decrease in oil import and pollution of the environment in the vicinity of railway infrastructure. In addition, the paper points out ecological problems which follow production of electricity in Thermal Power Plants (TPPs) in Serbia. Results of the previous geotechnical laboratory testing [24] showed that investigated fly ash and slag produced in TPPs in Serbia could be suitable for utilisation in the railway infrastructure. For the purpose of research presented in this paper, chemical laboratory testing was performed in order to assess the ecological suitability of fly ash as a material for the railway substructure.

\section{SUSTAINABLE RAIL TRANSPORT IN THE REPUBLIC OF SERBIA}

An uprising of environmental legal rights, responsibilities and consequences, as well as media campaigns and incorporation of environmental issues in education, have contributed to the development of ecological awareness of citizens around the world. Current practical experience clearly shows that ecological awareness of people is not a sufficient condition for the modal shift to ecologically acceptable transport ('modal shift to rail' concept). Regardless of the fact that railway system might provide sustainable transport of goods and people, the 'modal shift to rail' process is very slow.

The results of the conducted surveys show that passengers choose the transport mode regarding travel duration, vehicle comfort, travel distance, personal impression of safety, connections to other modes of transport (interchange possibility), ticket price and environmental 
protection. These surveys were conducted by the authors of this paper in Belgrade in 2012 [21] and in 2016 (Fig. 1). It is worth noting that the ticket price is a very important but not the decisive criterion. In addition, the awareness on the environmental protection is a growing but not a decisive criterion either. Consequently, Fig. 1 shows the average grades (grade scale from 1 - not important to 5 - the most important) that respondents gave to the offered criteria for travel mode choice.

Two European traffic corridors pass through Serbia (the Danube Corridor VII and the road-railway Corridor X) and Route 4 from the Romanian border through Belgrade to the Adriatic Sea. Therefore, the transport development in Serbia is planned within the framework of European policy. Obviously, the good position of Serbian rail network on the
European transport network and the development of ecological awareness of the citizens are not a sufficient condition for the successful 'modal shift to rail' concept. It is necessary to analyse and determine different expectations and needs of all potential users.

Tab. 1 clearly shows the discrepancy between the official transport policy and its implementation in the Republic of Serbia. Despite the fact that modern railway infrastructure has to represent a segment in the combined transportation chain in the 'door to door' concept for passengers and goods, lack of infrastructure for intermodal transport can be observed, as well as poor related services. In addition, the lack of implementation of the 'polluter pays' principle makes the rail transport less competitive compared to other transport modes.
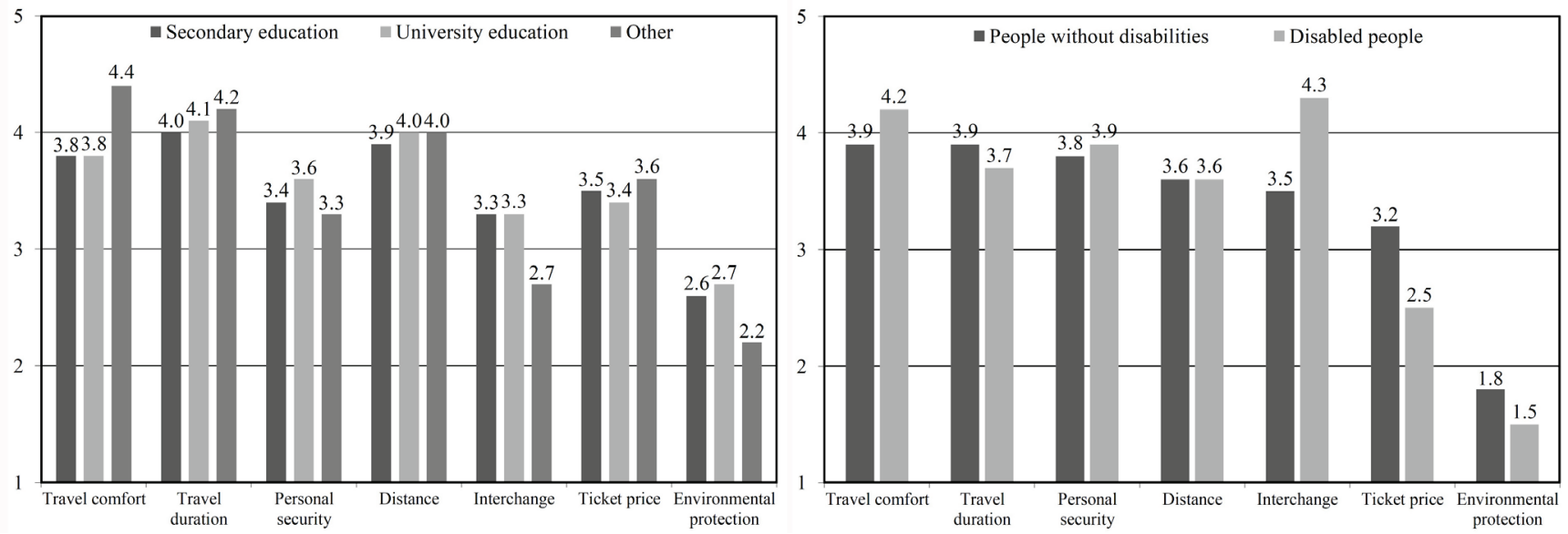

Figure 1 The average grades for the modal split criteria: (left) results according to the education level of respondents from 2016 survey, and (right) results according to respondent's mobility from 2012 survey [21]

Table 1 Performances of rail, road and air transport in Serbia [27]

\begin{tabular}{|c|c|c|c|c|c|c|c|}
\hline \multicolumn{3}{|c|}{ Statistically analysed years } & 2011 & 2012 & 2013 & 2014 & 2015 \\
\hline \multicolumn{2}{|c|}{ Passenger capacity, thous. passengers } & \multirow{6}{*}{$\begin{array}{c}\text { Railway } \\
\text { transport in } \\
\text { period } \\
2011-2015\end{array}$} & 49 & 48 & 48 & 45 & 56 \\
\hline \multicolumn{2}{|c|}{ Carrying capacity, thous. $\mathrm{t}$} & & 430 & 431 & 431 & 432 & 432 \\
\hline \multicolumn{2}{|c|}{ Passenger-kilometres, mill. pkm } & & 541 & 540 & 612 & 453 & 509 \\
\hline \multicolumn{2}{|c|}{ Ton-kilometres, mill. tkm } & & 3611 & 2769 & 3022 & 2988 & 3249 \\
\hline \multirow{2}{*}{ Consumption of: } & liquid fuels, thousand tons & & 10 & 9 & 9 & 9 & 10 \\
\hline & electricity, thousand MWh & & 170 & 143 & 148 & 139 & 136 \\
\hline \multicolumn{2}{|c|}{ Passenger capacity, thousand passengers } & & 122 & 125 & 120 & 116 & 119 \\
\hline \multicolumn{2}{|c|}{ Carrying capacity, thousand $t$} & & 53 & 65 & 72 & 80 & 110 \\
\hline \multicolumn{2}{|c|}{ Passenger-kilometres, mill. pkm } & Road transport & 4652 & 4640 & 4612 & 4223 & 4601 \\
\hline \multicolumn{2}{|c|}{ Ton-kilometres, mill. tkm } & & 1907 & 2474 & 2824 & 2959 & 2974 \\
\hline \multicolumn{2}{|c|}{ Consumption of liquid fuels, thousand tons } & & 97 & 111 & 116 & 120 & 138 \\
\hline \multicolumn{2}{|c|}{ Passenger capacity, thous. passengers } & & 1,7 & 1,7 & 1,7 & 2,0 & 1,4 \\
\hline \multicolumn{2}{|c|}{ Carrying capacity, thous. $\mathrm{t}$} & Air transport & 0,2 & 0,2 & 0,2 & 0,2 & 0,2 \\
\hline \multicolumn{2}{|c|}{ Passenger-kilometres, mill. pkm } & in period & 1412 & 1427 & 1471 & 2454 & 2642 \\
\hline \multicolumn{2}{|c|}{ Ton-kilometres, mill. tkm } & 2011-2015 & 2,7 & 1,9 & 1,9 & 3,3 & 4,7 \\
\hline \multicolumn{2}{|c|}{ Consumption of liquid fuels, thousand tons } & & 69 & 60 & 70 & 105 & 107 \\
\hline
\end{tabular}

The structure of passenger flow depends on the total population structure in each country. An increasing number and proportion of older individuals in the total population is noticeable in developed countries, as it is reported in [25]. Unfortunately, Serbia is currently among ten countries with the oldest population in the world [26]. According to official statistics, there are about 571780 people with different degree of disability (about $8 \%$ ), as well as $17,4 \%$ persons aged 65 and older.

Therefore, it is necessary to develop appropriate railway infrastructure and vehicles as well as related services. Modern infrastructure in railway stations, accessibility for all passengers including people with reduced mobility, effective interchanges, comfortable vehicles with modern equipment, related services, stimulation of multimodal transport of passengers and goods, acceptable prices and reliable transport may provide competitiveness of railways.

An intensive utilisation of the sustainable railway infrastructure, vehicles and related services, designed to meet customer needs, should contribute to the protection and improvement of environmental quality. Contrary to the statement that 'Rail infrastructure shapes the mobility of tomorrow' [2], Serbian experience shows that the infrastructure is not a sufficient condition for shaping the mobility. There are necessary related services, application of telematics, good connections to other modes of transport 
(interchange terminals and integrated timetables for transport chain) and the consistent implementation of a sustainable transport policy which creates conditions for regulated competition of different modes of transport. Further, an inappropriate railway infrastructure could not provide modal shift to rail and efficient transport of passengers and goods.

Reconstruction, maintenance and development of railway infrastructure for sustainable development of the Serbian transport system have to meet the required capacity levels and quality standards relevant to connect to TEN-T network in accordance with [28].

The Republic of Serbia has $3809 \mathrm{~km}$ of track, including $865 \mathrm{~km}$ of track on Corridor X, 546 railway stations, 1279 $\mathrm{km}$ of electrified railway network, including $283 \mathrm{~km}$ of double tracks (data source: the Serbian Railways Company 2016). Rail transport is of great importance for the development of Serbia. Serbian rail transport takes second place in transportation of passengers and goods today. The main advantage of rail transport is the ability to transport large volumes and weights of goods over long distances. The additional benefits are the increase in road safety, spatial efficiency, lower energy consumption and less pollution of the environment.

\section{RAILWAY ELECTRIFICATION AND ENVIRONMENTAL ISSUES}

Fulfilment of the Kyoto Protocol obligations that include greenhouse gas $(\mathrm{GHG})$ emission $\left(\mathrm{CO}_{2}\right.$ - carbon dioxide, $\mathrm{CH}_{4}$ - methane and $\mathrm{N}_{2} \mathrm{O}$ - nitrous oxide) reduction is a legal requirement for signatory countries (e.g. entry into force in Serbia on $17^{\text {th }}$ January 2008). As it is well known, the global warming potential of $\mathrm{GHG}$ emission is expressed as a carbon footprint and reported in $\mathrm{CO}_{2}$ equivalent mass units.

In general, the railway system has a lower carbon footprint compared to other modes of transport. In each specific case, the structure and amount of railway carbon footprint may be different. Therefore, the local specificities related to railway infrastructure, rolling stock, service, and mobility should be taken into account.

Sustainable transport policy defines development courses for the utilisation of energy from renewable and new sources and energy efficiency improvement. Therefore, railway electrification has to be based on renewable energy sources.

Unfortunately, high percentage of fossil fuels in electricity production adversely affects the carbon footprint of railway transport in the Republic of Serbia. Likewise, many diesel locomotives on the Serbian railway network emit combustion products and they are significant contributors to air pollution. It is necessary to control air pollution by reduction of fuel consumption, growth of energy efficiency, and use of alternative fuels.

Currently, 32,7\% of tracks were electrified in Serbia. In addition, the electrification of $254 \mathrm{~km}$ of Serbian tracks is planned. The characteristics of the railway network, the planned railway projects and the position of TPPs were shown in detail in [24]. Unfortunately, railway electrification does not necessarily contribute to the environmental protection. The electric power system in Serbia is mostly based on the utilisation of coal in
Obrenovac, Kostolac and Svilajnac TPPs, which are the main suppliers of electric power (Fig. 2, right). The estimated potential of renewable energy sources in Serbia is 5,6 million tons of oil equivalent per year. The structure of renewable energy sources includes: $63 \%$ biomass potential, $17 \%$ solar energy, $10 \%$ small watercourse potential, $5 \%$ wind energy, and 5\% geothermal energy (information according to the Public Enterprise Electric Power Industry of Serbia, 2016).

The installed capacity of power plants in Serbia is 8359 MW (Fig. 2, left) of which $61,86 \%$ is produced in lignitefired TPPs. Therefore, this case shows that production of electric power impacts the environment through air pollution, landfills, water and food contamination in the area of TPPs. Around 7 million tons/year of fly ash and slag are produced in Serbian TPPs. Currently, about 300 million tons of fly ash and slag are disposed on the landfills in the vicinity of TPPs (Fig. 2, left), taking up to 1600 hectares of fertile land. Hence, a permanent solution is a gradual reduction of the share that TPPs have in electricity production and increase of the share of energy from renewable and new sources.

According to [29], the biggest investments in the Republic of Serbia from 2011 to 2030 are expected in the sectors of water (EUR 5,6 billion), waste (EUR 2,8 billion), and industrial pollution and air (EUR 2,0 billion).

\section{ECOLOGICAL SUITABILITY OF FLY ASH FOR UTILISATION IN THE RAILWAY INFRASTRUCTURE}

The results of geotechnical laboratory testing [30] showed that investigated fly ash (produced in TPPs in Serbia) could be suitable for utilisation in the railway infrastructure for [24]:

- stabilization of soft subsoil,

- construction of embankment (using fly ash, with the core of ash (Fig. 3, type 1), or using soil stabilized with ash),

- construction of prepared formation layer using fly ash with cement or lime activators (Fig. 3, type 2),

- fly ash stabilization of bearing layer in slab track structure.

Before the practical utilisation of fly ash for the construction of the railway substructure, the risk of leaching of hazardous substances must be investigated (Fig. 3). The responsibility of the Infrastructure Management is great due to the risk of leaching which could jeopardize the environment, mainly soil and water.

If it is proven that there is no leaching of hazardous substances that threaten the environment, utilisation of fly ash and slag for the railway substructure would lead to multiple environmental and economic effects.

Fly ash from TPPs in Serbia belongs to class $\mathrm{F}$ according to ASTM C618 [31] or siliceous - type V according to EN 197-1 [32], as reported in [33]. These types of fly ash are mainly used for the construction of embankments and subsoil stabilization with the addition of lime or cement due to low content of reactive $\mathrm{CaO}$ (less than $10 \%$ ). The chemical composition of fly ash from TPPs is given in Tab. 2. The presented values are not constant - the content of chemical components changes over time depending on the composition of the coal.

The essential requirements that fly ash and slag should fulfil for use in civil engineering from the standpoint of the 
environment is the content of radionuclides and trace elements that do not exceed prescribed limits.
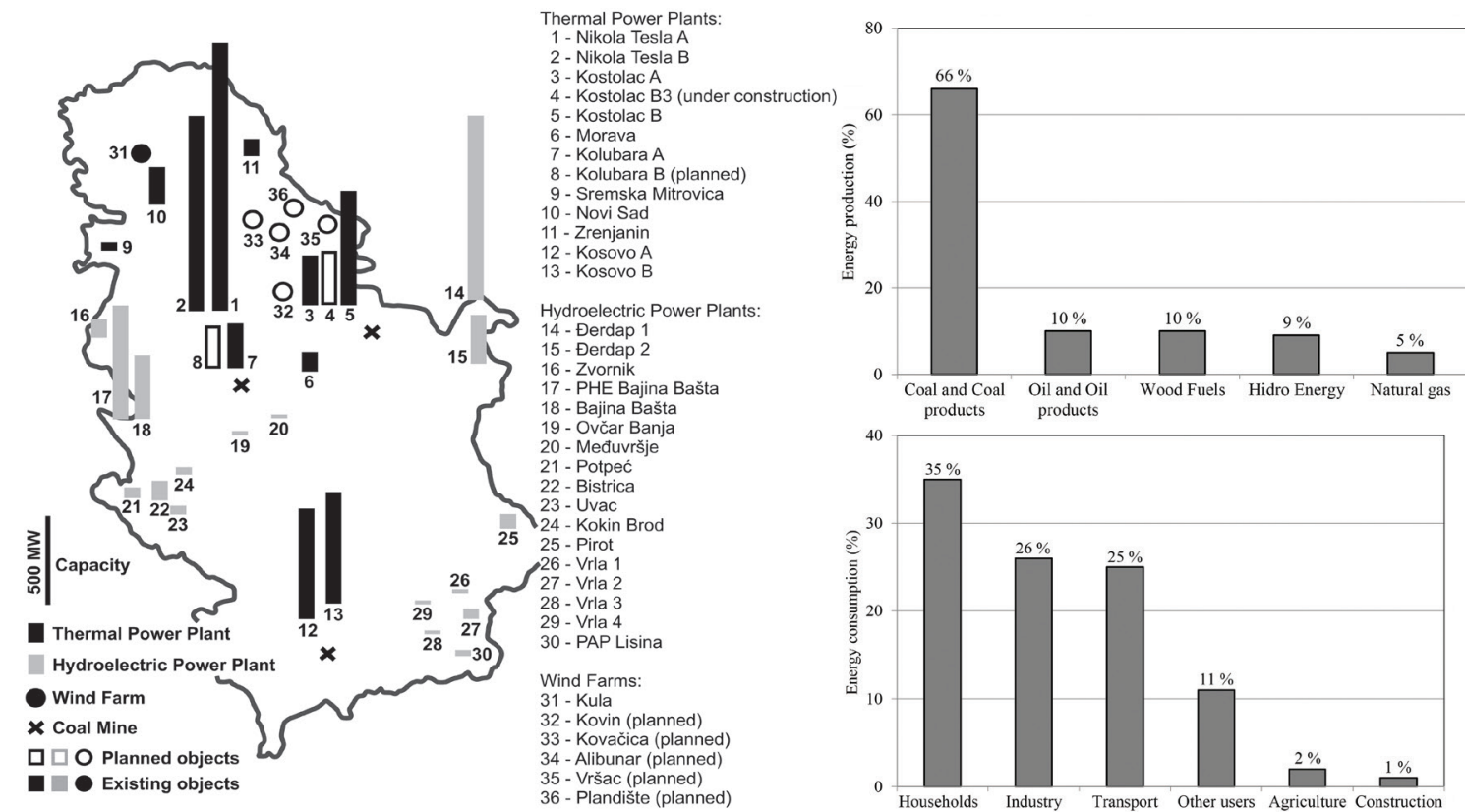

Figure 2 Locations of electric power plants in Serbia (left) and final consumption (right) in 2015

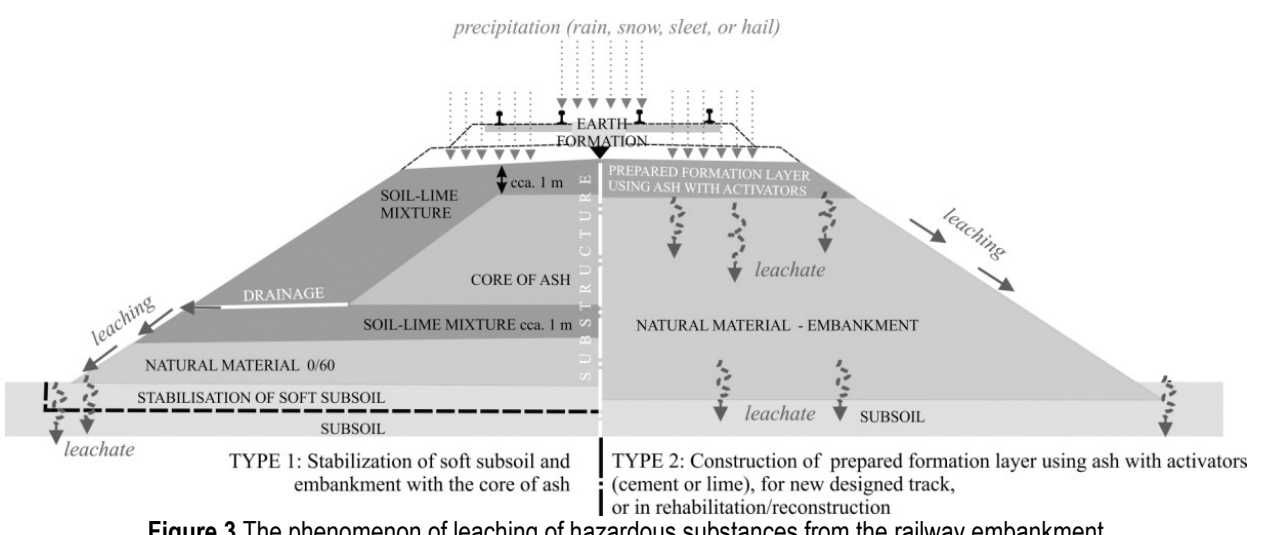

Figure 3 The phenomenon of leaching of hazardous substances from the railway embankment

Table 2 The chemical composition of fly ash from TPPs in Serbia [34]

\begin{tabular}{|c|c|c|c|c|}
\hline \multirow[b]{2}{*}{ Chemical compound of the fly ash sample } & \multicolumn{4}{|c|}{ Thermal Power Plants in Serbia } \\
\hline & $\begin{array}{l}\text { 'Nikola Tesla A' } \\
\text { (TENT A) }\end{array}$ & $\begin{array}{l}\text { 'Nikola Tesla B' } \\
\text { (TENT B) }\end{array}$ & $\begin{array}{l}\text { 'Kostolac A' } \\
\text { (TEKO A) }\end{array}$ & $\begin{array}{l}\text { 'Kostolac B' } \\
\text { (TEKO B) }\end{array}$ \\
\hline $\mathrm{SiO}_{2}, \%$ & 53,59 & 59,73 & 57,49 & 55,28 \\
\hline $\mathrm{Al}_{2} \mathrm{O}_{3}, \%$ & 21,18 & 20,97 & 17,72 & 17,43 \\
\hline $\mathrm{Fe}_{2} \mathrm{O}_{3}, \%$ & 6,20 & 5,99 & 10,48 & 10,31 \\
\hline $\mathrm{TiO}_{2}, \%$ & 0,56 & 0,57 & 0,52 & 0,52 \\
\hline $\mathrm{CaO}, \%$ & 7,61 & 5,83 & 6,96 & 7,96 \\
\hline $\mathrm{MgO}, \%$ & 2,74 & 2,21 & 1,98 & 2,28 \\
\hline $\mathrm{P}_{2} \mathrm{O}_{5}, \%$ & 0,027 & 0,023 & 0,022 & 0,029 \\
\hline $\mathrm{SO}_{3}, \%$ & 0,78 & 0,48 & 1,06 & 0,85 \\
\hline $\mathrm{Na}_{2} \mathrm{O}, \%$ & 0,44 & 0,41 & 0,36 & 0,40 \\
\hline $\mathrm{K}_{2} \mathrm{O}, \%$ & 1,22 & 1,18 & 0,59 & 0,55 \\
\hline $\mathrm{MnO}, \%$ & 0,030 & 0,030 & 0,028 & 0,026 \\
\hline $\mathrm{CO}_{2}, \%$ & 0,25 & 0,07 & 0,09 & 0,28 \\
\hline Content of reactive $\mathrm{SiO}_{2}, \%$ & 45,13 & 39,68 & 46,97 & 42,01 \\
\hline Content of reactive $\mathrm{CaO}, \%$ & 6,74 & 5,40 & 6,10 & 7,00 \\
\hline
\end{tabular}

\subsection{Content of Radionuclides in Fly Ash}

Control of the radionuclides content in the fly ash is very important because it can be a source of increased gamma radiation. Coal (lignite) and fly ash from TPPs in Serbia contain natural radionuclides ${ }^{40} \mathrm{~K},{ }^{226} \mathrm{Ra},{ }^{232} \mathrm{Th},{ }^{238} \mathrm{U}$, as well as the artificial ${ }^{137} \mathrm{Cs}$ originating from the accident at the Chernobyl nuclear power plant. The concentration of natural radionuclides in coal, slag and fly ash depend on the type of coal and the combustion methods in boilers of TPPs.

The gamma spectrometric analysis of natural and artificial radionuclides of the uranium and thorium series, and ${ }^{40} \mathrm{~K}$ was performed in [35]. 
Fig. 4 shows the content of natural radionuclides according to the measurement results from TENT A and TENT B for a 10 years period. It may be noted that in the process of coal combustion, increase of radionuclides concentration corresponds to the results published in [36].

The results of gamma spectrometric analysis of the content of artificial radionuclide ${ }^{137} \mathrm{Cs}$ on 8 samples of fly ash from TENT A and TENT B [37] show that the concentration is generally less than $1 \mathrm{~Bq} / \mathrm{kg}$.

According to [38], industrial waste material should not be disposed in the environment if the content of natural and artificial radionuclides is greater than the prescribed limits of radioactive contamination given in Tab. 3 .

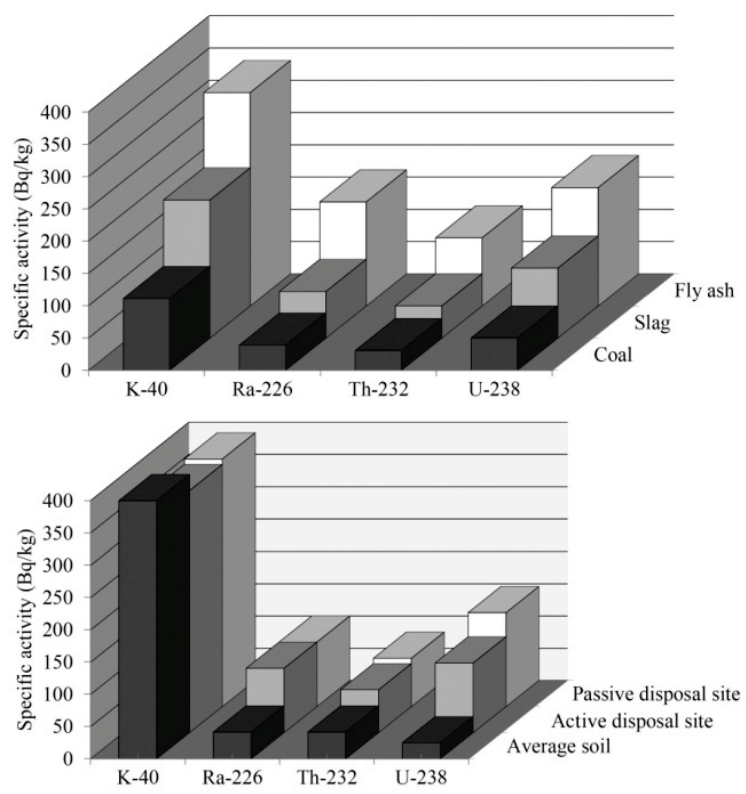

Figure 4 Content of natural radionuclides in: (up) coal, slag and fly ash, (down) average soil, active and passive disposal sites

Concentration of ${ }^{226} \mathrm{Ra},{ }^{232} \mathrm{Th},{ }^{40} \mathrm{~K}$ and sum of all artificial radionuclides in disposal material should fulfil Eq. (1):

$\frac{{ }^{226} \mathrm{Ra}\left(\frac{\mathrm{Bq}}{\mathrm{kg}}\right)}{4000}+\frac{{ }^{232} \mathrm{Th}\left(\frac{\mathrm{Bq}}{\mathrm{kg}}\right)}{3000}+\frac{{ }^{40} \mathrm{~K}\left(\frac{\mathrm{Bq}}{\mathrm{kg}}\right)}{5000}+\frac{\sum A R\left(\frac{\mathrm{Bq}}{\mathrm{kg}}\right)}{10000} \leq 1$

Permissible activity per quantity of radionuclides in construction materials for transport infrastructure is the following: $7 \times 10^{2} \mathrm{~Bq} / \mathrm{kg}$ for radium $\left({ }^{226} \mathrm{Ra}\right), 5 \times 10^{2} \mathrm{~Bq} / \mathrm{kg}$ for thorium $\left({ }^{232} \mathrm{Th}\right)$, and $8 \times 10^{3} \mathrm{~Bq} / \mathrm{kg}$ for potassium $\left({ }^{40} \mathrm{~K}\right)$.

Table 3 The limits of permissible specific activity [38]

\begin{tabular}{|c|c|}
\hline Radionuclides & $\begin{array}{c}\text { The limits of permissible specific } \\
\text { activity }(\mathrm{Bq} / \mathrm{kg})\end{array}$ \\
\hline${ }^{226} \mathrm{Ra}$ & 4000 \\
\hline${ }^{232} \mathrm{Th}$ & 3000 \\
\hline${ }^{40} \mathrm{~K}$ & 50000 \\
\hline $\begin{array}{c}\text { The sum of all artificial } \\
\text { radionuclides }\end{array}$ & 10000 \\
\hline
\end{tabular}

Gamma index, defined with Eq. (2), for construction materials for transport infrastructure should not exceed 1.

$I=\frac{C_{\mathrm{Ra}}}{700}+\frac{C_{\mathrm{Th}}}{500}+\frac{C_{\mathrm{K}}}{8000} \leq 1$
The results of measurements in landfills of TENT A and TENT B show that fly ash disposed into the environment meets these criteria. Artificial radionuclides were not detected in investigated samples of coal, fly ash and slag. In addition, artificial radionuclides with short half-lives were not detected in investigated samples.

The contents of radionuclides in agricultural land in the vicinity of the landfills do not differ significantly from the corresponding land beyond the area influenced by the plant's operation.

\subsection{Content of Trace Elements}

Fly ash is viewed as a great potential source for release of many environmentally hazardous elements, such as the following trace elements: $\mathrm{As}, \mathrm{Cd}, \mathrm{Co}, \mathrm{Cr}, \mathrm{Cu}, \mathrm{Fe}, \mathrm{Hg}, \mathrm{Mn}$, $\mathrm{Ni}, \mathrm{Pb}, \mathrm{V}$, and $\mathrm{Zn}$. These elements could enter the nearby soil, freshwater and/or marine ecosystems, or could be transmitted through the atmosphere over long distances.

Tab. 4 shows the contents of trace elements in fly ash from TPPs in Serbia (TENT A, TENT B, TEKO A and TEKO B). If the contents of trace elements in fly ash from TPPs are compared to reference values [39], it can be concluded that the fly ash could be considered as the nonhazardous waste. However, fly ash can be harmful to the environment if it is disposed at inert waste landfills.

\subsection{Ecological Aspects of the Fly Ash Utilisation}

Assessing the environmental influence of products based on the content of trace elements leads to unreliable and highly overestimated predictions of the risk level, which would limit fly ash utilisation. The potential environmental impact of fly ash depends on the leaching behaviour of the trace elements. Regardless of the different types of coal, there are some general trends in the leaching behaviour. This suggests that the factors that control the leaching from fly ash do not differ significantly. Understanding the reasons of the trace elements mobility is a key for better control over environmental impacts [40]. There is a wide range of standardised leaching tests. Among them, three methods are commonly used in EU: batch leaching tests according to EN 12457-2 [41], EN 12457-3 [42], and EN 12457-4 [43], the column leaching test according to CEN/TS 14405 [44], $\mathrm{pH}$ dependence leaching test according to CEN/TS 14429 [45]. At European level, the leaching tests are necessary in German, Dutch and French standards [46]. Previously stated standards (EN 12457-2, EN 12457-3, EN 12457-4) are mostly used in EU countries. The main factors that affect the selection of a suitable leaching method are climate conditions of the area, rainfall data, water head and flow rate to simulate the real situation [47].

From the environmental aspect, the main concern should be directed towards As, B, Cr, Mo and Se. These elements stand out as a potentially harm for altogether people, animals and plants, due to the high water solubility and therefore mobility in surface and ground waters. However, there are solutions for the reduction of the leaching of some toxic trace elements. For example, in the presence of $\mathrm{Ca}$, the leachability of As is attenuated due to the occurrence of solubility limiting phases. The precipitation of secondary phases such as ettringite (addition of lime and $\left.\mathrm{Al}(\mathrm{OH})_{3}\right)$ may capture and bind pollutants such as $\mathrm{As}, \mathrm{B}, \mathrm{Cr}$, 
$\mathrm{Sb}$ and Se. Described process would lead to the large reduction of these elements in solution [40].

Bearing in mind that the fly ash from TPPs in Serbia is siliceous type V [33], which is mostly used with the addition of lime (or cement), the problem with As and Se can be solved as described above. This is proven with the leaching tests results of fly ash from TPP 'Morava' after the addition of lime (see Tab. 5, values in parentheses).

Table 4 Contents of trace elements in fly ash from TPPs in Serbia

\begin{tabular}{|c|c|c|c|c|c|}
\hline \multirow{2}{*}{ Trace elements in fly ash $(\mathrm{mg} / \mathrm{kg})$} & \multicolumn{4}{|c|}{ Thermal power plants in Serbia } & \multirow{2}{*}{ Reference values } \\
\hline & *TENT A & *TENT B & *TEKO A & *TEKO B & \\
\hline $\mathrm{Pb}$ & $<0,09$ & $<0,09$ & $<0,09$ & $<0,09$ & $100(0,5)$ \\
\hline $\mathrm{Cd}$ & $<0,01$ & $<0,01$ & $<0,01$ & $<0,01$ & $5(0,04)$ \\
\hline $\mathrm{Zn}$ & 0,19 & 0,12 & 0,26 & 0,17 & $1000(4)$ \\
\hline $\mathrm{Cu}$ & 0,08 & 0,05 & 0,05 & 0,05 & $100(2)$ \\
\hline $\mathrm{Ni}$ & $<0,04$ & $<0,04$ & $<0,04$ & $<0,04$ & $500(0,4)$ \\
\hline $\mathrm{Cr}$ & 1,87 & 4,36 & 0,86 & 0,45 & $300(0,5)$ \\
\hline $\mathrm{Hg}$ & $<0,01$ & $<0,01$ & $<0,01$ & $<0,01$ & $0,5(0,01)$ \\
\hline As & 0,30 & $\mathbf{0 , 7 8}$ & 0,29 & 0,33 & $50(0,5)$ \\
\hline $\mathrm{Ba}$ & 2,22 & 4,05 & 3,57 & 4,54 & $500(20)$ \\
\hline $\mathrm{Se}$ & $<0,10$ & $<0,10$ & $<0,10$ & $<0,10$ & $50(0,1)$ \\
\hline
\end{tabular}

*Source: Study by [34] and Testing method according to [47]

Note: The reference values shown in table refer to the limits for hazardous waste, the values in parentheses refer to the limits for waste disposal at inert waste landfills according to Regulation on the classification, packaging and storage of secondary raw materials [39].

Table 5 Content of trace elements after leaching tests in fly ash from TPP 'Morava'

\begin{tabular}{|c|c|c|c|c|c|c|c|c|c|c|}
\hline & \multicolumn{10}{|c|}{ Content of trace elements in fly ash after leaching tests** $(\mathrm{mg} / \mathrm{kg})$} \\
\hline & $\mathrm{Pb}$ & $\mathrm{Cd}$ & $\mathrm{Zn}$ & $\mathrm{Cu}$ & $\mathrm{Ni}$ & $\mathrm{Cr}$ & $\mathrm{Hg}$ & As & $\mathrm{Ba}$ & $\mathrm{Se}$ \\
\hline Samples 1 & 0,11 & 0,01 & 0,74 & 1,05 & 0,11 & 0,12 & $<0,01$ & 2,16 & 0,36 & 0,32 \\
\hline Samples 2 & 0,20 & 0,00 & 0,5 & 0,1 & 0,2 & 0,5 & $<0,01$ & 0,3 & 1,1 & 0,1 \\
\hline $\begin{array}{l}\text { Samples } 1 \text { - Fly ash only; Sa1 } \\
\text { Limit values - Limit values f } \\
* * \text { According to the on-going }\end{array}$ & $\begin{array}{l}\text { vith a } \\
\text { for } r\end{array}$ & $\begin{array}{l}\text { of } 5 \\
\text { onstru }\end{array}$ & $\begin{array}{l}\text { lime } \\
\text { acco }\end{array}$ & $\begin{array}{l}\text { ting } \\
\text { to }[4\end{array}$ & & & S 144 & & & \\
\hline
\end{tabular}

Only one research that dealt with the environmental aspects of the utilisation of fly ash from TPPs in Serbia was published so far [49]. This research dealt with the analysis of the hydraulic (transport) characteristics of fly ash and effect of stabilizer (lime or cement) on its properties. Results showed that the effect of the stabilizers, particularly cement, increased the pollutant residence time by up to nine times. These hydraulic (transport) parameters are important and would be taken into consideration in fly ash utilisation, particularly in respect of its potential impact and influence on the environment. These results show that fly ash is not a pollutant if it is properly used. In addition, it can even reduce the impact of other pollutants. However, after positive results in the laboratory investigations, it is necessary to investigate leaching properties of fly ash in real conditions on embankment constructed using fly ash.

\section{CONCLUSION}

The railway system is still a transport mode with unutilised capacity and ecological potential in Serbia. This paper points out that the railway infrastructure and environmental awareness of citizens are not the sufficient conditions for realization of the 'modal shift to rail' concept, which should be an integral part of sustainable development of transport. In addition, the results of two surveys (conducted in Belgrade in 2012 and 2016) are presented and they show that the awareness on the environmental protection is a growing but not a decisive criterion for travel mode choice in Serbia. The environmental advantages of rail transport could be realized by development of modern railway infrastructure, vehicles and related services, which have to be adapted for real needs of all customers (transport of passengers and goods). At the same time, development of railway transport should protect and improve the integrity of the environment. The paper discusses particularly delicate relations between railway infrastructure and environment, and suggests that the policy of sustainable transport development and the legal framework for its realization, which is based on 'user pays - polluter pays' principle [2], are crucial for fulfilment of environmental requirements.

This paper deals with complex requirements for railway infrastructure and indicates that these ones can often be opposed to each other. Accordingly, planned electrification of the existing and new railway lines would contribute to the further degradation of the environment due to the high percentage of fossil fuels in electricity production. The long term solution can be found in utilisation of energy from renewable and new sources and energy efficiency improvement of the power plants. In the meantime, it is necessary to find the best solution for the removal of fly ash and slag landfills. The paper deals with the possible utilisation of fly ash for the construction of railway infrastructure to protect the environment and to achieve the economic benefits. It was concluded that the favourable geotechnical properties are not sufficient condition for the application of fly ash for construction of railway embankment and subsoil stabilization.

From the aspect of the environment, essential requirements for fly ash utilisation in civil engineering are the content of radionuclides and trace elements according to prescribed limits. The paper presents the results of laboratory testing of radionuclides and trace elements content in the samples of fly ash from thermal power plants (TTPs) in Serbia. Measured activity of natural radionuclides in coal depends on the type of the used coal. The results of measurements in landfills of two TPPs show that the content of radionuclides in the disposed fly ash and slag are within the prescribed limits. Regarding the content 
of trace elements, fly ash and slag is classified as nonhazardous waste, but it can be harmful to the environment if it is disposed at inert waste landfills. For utilisation of fly ash for transport infrastructure, the substantial potential environmental impact depends on the leaching behaviour of the trace elements. Namely, control of the trace elements' mobility is a key question for the control of environmental impact. This means that excessive leaching of some trace elements could be removed or reduced by appropriate procedures. The paper presents the impact of adding lime to the reduction of As and Se leaching from fly ash from TPP. After positive results of the laboratory testing, it is necessary to investigate the risk of leaching of hazardous substances from the railway embankment in the field.

Proving that there is no risk of leaching would ensure that fly ash is suitable for construction of railway infrastructure. Further, application of fly ash would lead to the reduction of demand for natural materials and to the removal of fly ash from landfills in the vicinity of TPPs.

\section{Acknowledgements}

Authors are grateful to the support of Electric Power Industry of Serbia.

Authors acknowledge the support of research project TR 36012, "Research of technical-technological, staff and organisational capacity of Serbian Railways, from the viewpoint of current and future European Union requirements", funded by the Ministry of Education and Science of the Republic of Serbia.

\section{REFERENCES}

[1] European Commission. (2001). White paper - European transportation policy for 2010: Time to decide. / Office for official publications of the European communities, Luxembourg.

[2] European Commission. (2011). White paper, Roadmap to a Single European Transport Area - Towards a competitive and resource efficient transport system. / Brussels, Belgium.

[3] Republic of Serbia. (2009). Zakon o potvrđivanju Kjoto protokola uz okvirnu konvenciju Ujedinjenih Nacija o promeni klime. / Official Gazette of the Republic of Serbia, $38 / 09$.

[4] United Nations. (1998). Kyoto Protocol to the United Nations Framework Convention on Climate Change. / New York, USA.

[5] Republic of Serbia. (2014). Zakon o energetici. / Official Gazette of the Republic of Serbia, 145/14.

[6] European Commission. (2014). Technical specification for interoperability - Subsystem infrastructure. / Official journal of the European Union, L 356.

[7] European Commission. (2014). Technical specification for interoperability - People with reduced mobility. / Official journal of the European Union, L 356/110.

[8] Stanley, J. K., Hensher, D. A., \& Loader, C. (2011). Road Transport and Climate Change: Stepping off the Greenhouse Gas. Transportation Research Part A, 45, 1020-1030. https://doi.org/10.1016/j.tra.2009.04.005

[9] Oxley, T., Elshkaki, A., Kwiatkowski, L., Castillo, A., Scarbrough, T., \& ApSimon, H. (2012). Pollution Abatement from Road Transport: Cross-Sectoral Implications, Climate Co-benefits and Behavioural Change. Environmental Science \& Policy, 19-20, 16-32. https://doi.org/10.1016/j.envsci.2012.01.004
[10] Celauro, C., Corriere, F., Guerrieri, M., \& Lo Casto, B. (2015). Environmentally Appraising Different Pavement and Construction Scenarios: A Comparative Analysis for a Typical Local Road. Transportation Research Part D, 34, 41-51. https://doi.org/10.1016/j.trd.2014.10.001

[11] Celauro, C., Corriere, F., Guerrieri, M., Lo Casto, B., \& Rizzo, A. (2017). Environmental Analysis of Different Construction Techniques and Maintenance Activities for a Typical Local Road. Journal of Cleaner Production, 142, 3482-3489. https://doi.org/10.1016/j.jclepro.2016.10.119

[12] Ernst, J. \& Kieffer, E. (2006). Barrierefreies Reisen durch Harmonisierung der Einstiegshöhen. ETR Eisenbahn Technische Rundschau, 55, 281-288.

[13] European Commission. (2004). Passengers' accessibility to heavy rail systems. European research area: Structural aspects - COST Action 335. / Office for official publications of the European communities, Luxembourg.

[14] Popović, Z., Stevanović, K., \& Puzavac, L. (2009). Railway Terminals: Accessibility for Persons with Reduced Mobility. Spatium, 20, 60-67. https://doi.org/10.2298/SPAT0920060P

[15] Popović, Z., Puzavac, L., \& Lazarević, L. (2012). Improving the Accessibility of Passenger Railways in the Republic of Serbia. RTR-Railway Technical Review, 52, 25-29.

[16] Popović, Z. \& Lazarević, L. (2014). Public passenger transport for distances up to $800 \mathrm{~km}$. Put i saobraćaj, 60, 4959.

[17] UIC. (2001). Leaflet 140 Eurostations - Accessibility to Stations in Europe. / Paris, France.

[18] Matuška, J. (2014). Railway System Accessibility Evaluation for Wheelchair Users: Case Study in the Czech Republic. Transport, 32, 32-43. https://doi.org/10.3846/16484142.2014.941396

[19] Republic of Serbia. (2016). Zakon o sprečavanju diskriminacije osoba sa invaliditetom. / Official Gazette of the Republic of Serbia, 13/16.

[20] Popović, Z., Lazarević, L., \& Puzavac, L. (2012). The Potential for Passenger Rail Transportation in the Republic of Serbia. Proceedings of the $1^{\text {st }}$ International Conference on Railway Technology: Research, Development and Maintenance / Las Palmas, Spain, 2012, paper 168, 1-13. https://doi.org/10.4203/ccp.98.168

[21] Popović, Z., Puzavac, L., \& Lazarević, L. (2013). Passenger Railway in Serbia - State of the Art and Potential. TTEMTechnics Technologies Education Management, 8, 13121317.

[22] Stevanović, K. \& Popović, Z. (2013). Sustainable Urban Development - Terminal Novi Beograd - Morphological Potential. Proceedings of the International Conference on Sustainable Urban \& Transport Planning / Belgrade, Serbia, 2013, 256-270.

[23] Popović, Z., Lazarević, L., Vukićević, M., Vilotijević, M., \& Mirković, N. (2017). The modal shift to sustainable railway transport in Serbia. MATEC Web of Conferences, 106, 1-10. https://doi.org/10.1051/matecconf/201710605001

[24] Vukićević, M., Popović, Z., Despotović, J., \& Lazarević, L. (2018). Fly Ash and Slag Utilization for the Serbian Railway Substructure. Transport, 33, 389-398. https://doi.org/10.3846/16484142.2016.1252427

[25] European Commission. Eurostat. http://ec.europa.eu/ eurostat $/ \operatorname{tgm} /$ refreshTableAction.do?tab=table \& plugin $=1 \&$ pcode $=$ tps00010\&language $=$ en $(18.10 .2017)$

[26] Statistical Office of the Republic of Serbia. (2011). Populacija Srbije početkom 21. veka.

[27] Statistical Office of the Republic of Serbia. (2016). Statistical Yearbook. http://webrzs.stat.gov.rs/WebSite/ repository/documents/00/02/29/16/CEO_StatistickiGodisnj akRS_2016.pdf (18.10.2017)

[28] Italferr. (2009). General master plan for transport in Serbia. Final report 05SER01/04/016. http://www.seetoint.org/ 
wpcontent/uploads/downloads/2014/01/Serbia GeneralMaster-Plan-for-Transport-2009.pdf (18.10.2017)

[29] Ministry of Environment and Spatial Planning. (2011). National environmental approximation strategy for the Republic of Serbia. Official Gazette of the Republic of Serbia, 80/11.

[30] IMS Institute for Testing of Materials \& Faculty of Civil Engineering. (2015). Korišćenje letećeg pepela i šljake proizvedenih u TE JP EPS za potrebe železnice. Study report. / Belgrade, Serbia.

[31] American Society for Testing and Materials. (2015). C618 Standard specification for coal fly ash and raw or calcined natural pozzolan for use in concrete. https://www.astm.org/ Standards/C618.htm (18.10.2017)

[32] EN 197-1. (2011). Cement - Part 1: Composition, specifications and conformity criteria for common cements, CEN.

[33] Vukićević, M., Pujević, V., Marjanović, M., Jocković, S., \& Maraš-Dragojević, S. (2015). Stabilization of Fine-Grained Soils with Fly Ash. Građevinar, 67, 761-770. https://doi.org/10.14256/JCE.1281.2014

[34] Institute for Testing of Materials. (2011). Application and placement of ashes from EPS power plants Study report. / Belgrade, Serbia.

[35] Boris Kidric Institute of Nuclear Sciences. (1999). Kontrola radioaktivnosti u životnoj i radnoj okolini termoelektrana Nikola Tesla A i B (TENT A i TENT B), u Obrenovcu, u periodu od 1990. do 1999. godine. Study report. / Belgrade, Serbia.

[36] Pandit, G. G., Sahu, S. K., \& Puranik, V. D. (2011). Natural Radionuclides from Coal Fired Thermal Power PlantsEstimation of Atmospheric Release and Inhalation Risk. Radioprotection, 46, 173-179. https://doi.org/10.1051/radiopro/20116982s

[37] Vinča Institute of Nuclear Sciences. (2007). Gama spektrofotometrijska analiza sadržaja veštačkih radionuklida. Study report. / Belgrade, Serbia.

[38] Federal Republic of Yugoslavia. (1999). Pravilnik o granicama radioaktivne kontaminacije životne sredine i o načinu sprovođenja dekontaminacije. Official Gazette of FRY, 9/99.

[39] Ministry of Environment and Spatial Planning. (2010). Pravilnik o kategorijama, ispitivanju i klasifikaciji otpada. Official Gazette of the Republic of Serbia, 56/10.

[40] Izquierdo, M. \& Querol, X. (2012). Leaching Behaviour of Elements from Coal Combustion Fly Ash: An Overview. International Journal of Coal Geology, 94, 54-66. https://doi.org/10.1016/j.coal.2011.10.006

[41] EN 12457-2. (2002). Characterisation of waste - Leaching Compliance test for leaching of granular waste materials and sludges - Part 2: One stage batch test at a liquid to solid ratio of $10 \mathrm{l} / \mathrm{kg}$ for materials with particle size below $4 \mathrm{~mm}$ (without or with size reduction), CEN.

[42] EN 12457-3. (2002). Characterisation of waste - Leaching Compliance test for leaching of granular waste materials and sludges - Part 3: Two stage batch test at a liquid to solid ratio of $2 \mathrm{l} / \mathrm{kg}$ and $8 \mathrm{l} / \mathrm{kg}$ for materials with high solid content and with particle size below $4 \mathrm{~mm}$ (without or with size reduction), $\mathrm{CEN}$.

[43] EN 12457-4. (2002). Characterisation of waste - Leaching Compliance test for leaching of granular waste materials and sludges - Part 4: One stage batch test at a liquid to solid ratio of $101 / \mathrm{kg}$ for materials with particle size below $10 \mathrm{~mm}$ (without or with size reduction), CEN

[44] CEN/TS 14405. (2004). Characterization of waste Leaching behaviour tests - Up-flow percolation test (under specified conditions), CEN

[45] CEN/TS 14429. (2005). Characterization of waste Leaching behaviour tests - Influence of $\mathrm{pH}$ on leaching with initial acid/base addition, CEN.
[46] Tiwari, M. K., Bajpai, S., Dewangan, U. K., \& Tamrakar, R. K. (2015). Suitability of Leaching Test Methods for Fly Ash and Slag: A Review. Journal of Radiation Research and Applied Sciences, 8, 523-537. https://doi.org/10.1016/j.jras.2015.06.003

[47] EN 16192. (2011). Characterization of waste - analysis of eluates, CEN.

[48] Service d'Études sur les Transports, les Routiers et Leurs Aménagements. Acceptability of alternative materials in road construction. (2011). http://www.centre-est.cerema.fr/ IMG/pdf/SETRA_2011-03_Valorisation_MA_Versionanglaise_cle12112a-1.pdf (18.10.2017)

[49] Stanić, F., Jaćimović, N., Ranđelović, A., \& Despotović, J. (2017). Laboratory Investigation of Hydraulic Characteristics of Fly Ash as Fill Material from the Aspect of Pollutant Transport. Water Science and Technology, 76, 976-982. https://doi.org/10.2166/wst.2017.243

\section{Contact information:}

Milica VILOTIJEVIĆ, MSc (corresponding author)

Faculty of Civil Engineering, University of Belgrade

Bulevar kralja Aleksandra 73, 11000 Belgrade, Serbia

E-mail: mvilotijevic@grf.bg.ac.rs

Mirjana VUKIĆEVIĆ, PhD

Faculty of Civil Engineering, University of Belgrade

Bulevar kralja Aleksandra 73, 11000 Belgrade, Serbia

E-mail: mirav@grf.bg.ac.rs

Luka LAZAREVIĆ, PhD

Faculty of Civil Engineering, University of Belgrade

Bulevar kralja Aleksandra 73, 11000 Belgrade, Serbia

E-mail: llazarevic@grf.bg.ac.rs

Zdenka POPOVIĆ, PhD

Faculty of Civil Engineering, University of Belgrade

Bulevar kralja Aleksandra 73, 11000 Belgrade, Serbia

E-mail: zdenka@grf.bg.ac.rs 